Sharif University of Technology
Scientia Iranica
Transactions A: Civil Engineering
SCIENTIA
IRAN I CA

\title{
Numerical analysis and back calculation for embankment dam based on monitoring results (Case study: Iran-Lurestan Rudbar)
}

\author{
V. Ghiasi ${ }^{\mathrm{a}, *}$, F. Heidari ${ }^{\mathrm{a}}$, and H. Behzadinezhad ${ }^{\mathrm{b}}$ \\ a. Department of Civil Engineering, University of Malayer, Hamadan, P.O. Box 65719-95863, Iran. \\ b. Department of Mining Engineering, Isfahan University of Technology, Isfahan, Iran.
}

Received 11 June 2020; received in revised form 5 February 2021; accepted 15 March 2021

\author{
KEYWORDS \\ Back calculation; \\ Monitoring; \\ Instrumentation; \\ FLAC 2D; \\ Rudbar rockfill dam.
}

\begin{abstract}
The present study aims to compare the results obtained from monitoring with those from numerical modeling in order to significantly facilitate the stability analysis for embankment dams. In addition to making a comparison between these analyses, which are the precise instrument results, this study validates the outcome of numerical analysis, thus forming a basis for carrying out back analysis to obtain accurate geotechnical parameters. Rudbar Lurestan dam was selected as the case study and the results of its instrumentation were processed and analyzed. The model was established in a static state at the time of construction. FLAC 2D V7 software was employed for modeling, and simulation was done using Mohr-Coulomb behavioral model and the initial parameters of the material (obtained from the laboratory). Then, upon completing the modeling at the end of construction and performing the initial impounding, the results of back calculation give us the final parameters of the materials. The consistency between the results of these analyses and design assumptions and instrumentation results was evaluated. The observations show that there is good agreement between the monitoring results of the modeling and, also, the final parameters obtained from the back calculation point to an increase in most parameters.
\end{abstract}

(C) 2021 Sharif University of Technology. All rights reserved.

\section{Introduction}

Earth and rockfill dams are important colossal structures. The initial materials used in construction of these dams include natural materials such as earth or rock. The behavior of these dams cannot be predicted in a well-defined and specific framework due to several

*. Corresponding author. Tel./Fax: 00988143213210 E-mail addresses: v.ghiasi@malayeru.ac.ir (V. Ghiasi); Farzad.heydari@stu.malayer.ac.ir (F. Heidari); h.behzadinezhad@yahoo.com (H.Behzadinezhad)

doi: 10.24200 /sci. 2021.56159 .4579 reasons such as their three-phase nature (soil, water, and air) and soil properties of materials. In addition, due to the high costs of dam construction and their susceptibility to heavy damages due to their insecurity, it is essential that the stability and monitoring of the dams during construction, impounding, and exploitation be closely managed. In addition, it is quite important to design and model the dams accurately. In the case of finding a behavioral model with realistic parameters, which is also consistent with the instrumental results, using a model able to study the dam behavior in different sections where the instrumentation is not installed or damaged is necessary. Given that some problems may occur over the course of impounding 
or exploitation, with proper modeling of the plan, dam safety can be ensured against accidents such as hydraulic failure and arching ratio. In this respect, the actual geotechnical parameters of the dam body can be obtained during construction, impounding, and operation.

Monitoring operations and studying the process of data changes obtained from the instrumentation used in the dams in many cases can prevent further destruction by predicting the occurrence of lateral and linear cracks, arching, hydraulic failure, and high stress, thus reducing possible damages to downstream of the dam. Therefore, taking control of dam behavior during construction, impounding, and exploitation is essential. In recent decades, dam sustainability has drawn engineers' attention.

One of the recommendations of the International Commission on Large Dams is to constantly control the safety and sustainability of dams during construction and exploitation [1]. The dams can be modified based on displacement monitoring data and penetration assessments. Park and Oh [2] discussed dam modification using low-pressure injection method. To reduce the impact of rock falls and protect the structures such as reinforced concrete, stone vents, retaining walls, and rigid and flexible dams, dams are widely constructed in mountainous areas [3,4]. Statistical information illustrates that earth dams are exposed to destruction more than concrete dams, and more than $50 \%$ of earth dam destructions or damages occur at the time of construction and during initial impounding [5]. The observation data of embankment dam displacement can obviously reflect the actual service behavior of the dam [6]. In the implementation of constructive and geotechnical projects, monitoring and surveying of the construction and structures are done with important objectives: construction control, warning against any imminent failure, quality assurance, validation of new theories, resolving of legal and judicial matters as quickly as possible, verification of long-term implementation and stability [7], and application of different types of geotechnical instrumentation as one of the most commonly used methods for the monitoring of geotechnical structures, especially in earth dams [8]. Researchers in the fields of engineering and economy maintain that in many cases of dam construction projects around the world, rock-fill dams with a clay core are so impervious that they are considered to be the best choice for the ultimate design [9]. Most dam failures experience a process of quantitative to qualitative changes [10].

Mahinrousta et al. [11] evaluated the linear behavior of rock fill materials using numerical analysis and laboratory test results. Strain hardening and softening model in the FLAC software were modified based on the data provided by laboratory examinations in order to estimate the failure phenomenon resulting from the settlement in the earth and rockfill dams at the time of flooding. The obtained results helped engineers better predict the nonlinear behavior of the failure phenomenon from the result of the settlement in the upstream crust.

The pore water pressure, stresses, and settlement are the main parameters for the stability analysis of earth and rockfill dams [12], as investigated in this study. Beiranvand and Komasi [13] analyzed the pore water pressure on the Eyvashan earth and rockfill dams in the initial impounding using two Plaxis and Geostudio software products. In addition, according to the data recorded by the instrumentation installed in the dam, there is no unexpected leakage phenomenon in this dam.

Dam safety monitoring as an essential task in risk management guarantees the normal operation of these infrastructure. Proper modeling and analysis of the structural responses under the given loads and ambient conditions as well as verifying the measured data with simulated ones are all essential tasks in dam safety monitoring. Seepage control is one of these tasks in dam surveillance, especially for earth dams [14]. Wang et al. [15] established a monitoring model to analyze the long-term trend and short-term fluctuation of a gravity dam seepage behavior, for which the support vector machine is used as a baseline model for prediction. Guo et al. [16] presented an analytical method for predicting the pore water pressure inside embankment dams.

Taham dam was numerically modeled using Plaxis software [17]. The values obtained from the modeling in the pore water pressure parameter were in good agreement; however, in case of stress, slight differences were observed.

In [18], the results of instrumentation and numerical analyses in the Siah Sang embankment dam were analyzed, indicating good agreement with the aforementioned results.

Implementation of back analysis in geotechnical engineering has been significantly expanded and widely recognized as a powerful tool for evaluating fieldmeasurement information. Among the most important reasons behind the popularity of back analysis among engineers are lack of laboratory restriction and inside tests and a complete description of soil profiles [19]. In 2008, Gikas and Sakellariou made a comparison between the various horizontal shapes obtained from monitoring the dam and the back numerical analysis of the earth dam. This dam was modeled using Z_soil software and Finite Element Method (FEN). Movements were measured at different stages of construction and exploitation of the dam. The settlement behavior of the Shuibuya dam at the time of construction, initial impounding, and after two years of exploitation was investigated. They also performed a two-dimensional 
numerical analysis using FEM and compared the results of the measured settlement using the instrumentation. Furthermore, they performed the back analysis using Hybrid General Algorithms (HGAs) [20]. The results indicated that this method could successfully control dam deformation. In addition, the results of settlement showed that after initial impounding, while the reservoir volume increased, the value of settlement decreased and tended to be fixed over time [21]. From back analysis in Geotechnical projects, studying the type of stability of slopes and correction methods of instability can be mentioned [22], analyzing types of tunnel, caverns and galleries stability [19], and also the calibration of models [23], analyzing, and estimation of probability of fracture expansion and its effect on the safety of concrete dams [24], analyzing earth and rock fill dams during all stages of construction and completion of construction [25]. The back analysis was used as a suitable method for selecting the foundation and loan sources [26]. Rashidi and Haeri investigated a method based on the back analysis performed on the Gavoshan dam in Kurdistan and obtained the actual parameters at the end of construction [27]. In 2017, Wen et al. evaluated measurement results obtained from a detailed deformation-monitoring system. In their study, the results of the numerical analyses and measurements were compared and then, the results of geodetic measurement were confirmed through numerical analyses [28].

Pramthawee et al. performed time-dependent analysis of a high rockfill dam. They compared the 3D finite element analyses with and without creep in a rockfill dam with in-situ measurements. In addition, measurement results were verified by numerical analyses [29].

Evaluation and control of the stability of earthly dams are of significance mainly due to the occurrence possibility of some phenomena such as settlement, hydraulic failure, leakage, and pore water pressure. Dam monitoring is a method for evaluating dam behavior in different states of construction, impounding, and exploitation. Numerical modeling is one of the methods of the analysis and control of earth and rockfill dams. A comparison between the monitoring and numerical modeling facilitates the stability analysis of these dams. A comparison between the results of this analysis and the real-world data indicates that they both yield the same instrumentation results and, consequently, validate the outcome of numerical analysis, thus forming a basis for performing back analysis to obtain precise geotechnical parameters. In this regard, the present study aims to extract the final parameters through applying back analysis method to earth and rockfill dams to predict their performance. Therefore, stability analysis was carried out, indicating that monitoring of earth and rockfill dams is essential; however, no study has investigated Lurestan-Rudbar dam so far. Hence, this study addressed this case study.

\section{Main features of Rudbar dam}

Rudbar dam, located $90 \mathrm{~km}$ away from Aligudarz, Lurestan Province, Iran, is situated on Dez River (Figure 1). This dam was constructed for several main reasons such as providing required water for agricultural use, producing electricity-watery energy (986 GW/year), reducing the cost of thermal power depreciation, and controlling the floodwater. To evaluate the behavior of Rudbar dam, different types of instrumentation including piezometers, measuring cells of the total pressure of the soil mass, and inclinometers were installed in three sections along the body of Rudbar-Lurestan dam that consists of several parts including the clay core, filter and transition zones, pebble shell, and upstream body slope protective layer (Rip Rap). The dam core consists of GC material with the maximum particle size of $75 \mathrm{~mm}$ as well as a filter material that comprises a fine-grained part with the maximum size of $20 \mathrm{~mm}$ and a coarse-grained part with the maximum size of $50 \mathrm{~mm}$. Moreover, the particle sizes of the transition zone or drain and dam crust are 20 and $120 \mathrm{~cm}$, respectively.

The core of the dam is protected by two-layer filters and a transitive drain in both upstream and downstream of the dam. The dam crust contains two parts: transitive crust or drain and rockfill crust. The transitive crust lies between the filter and shell rockfill. The outer part of the rockfill uppermost crust is also protected by a beaching layer. With respect to earth height, type of foundation, and depth of the valley, the most frequently installed instrumentation is in the C5-5 section, which is the most important and critical dam section in terms of maximum settlement, pore water pressure, and total stress. The critical section as well as different levels and zones of different parts are depicted in Figure 2. As shown in Figure 3, construction of Rudbar dam began in October 2011, the last layer of the embankment (for 24 months) finished in October 2017, and its initial impounding began in June and lasted until the next ten months, April 2017. The technical characteristics of Rudbar dam are presented in Table 1.

\section{Properties of materials and numerical modeling}

Rudbar dam was modeled using FLAC 2D software based on the difference method. Mohr-Coulomb elastoplastic model is a behavioral model used in the core, filters, upstream, and downstream.

\subsection{Properties of materials}

The properties of the materials used in numerical 


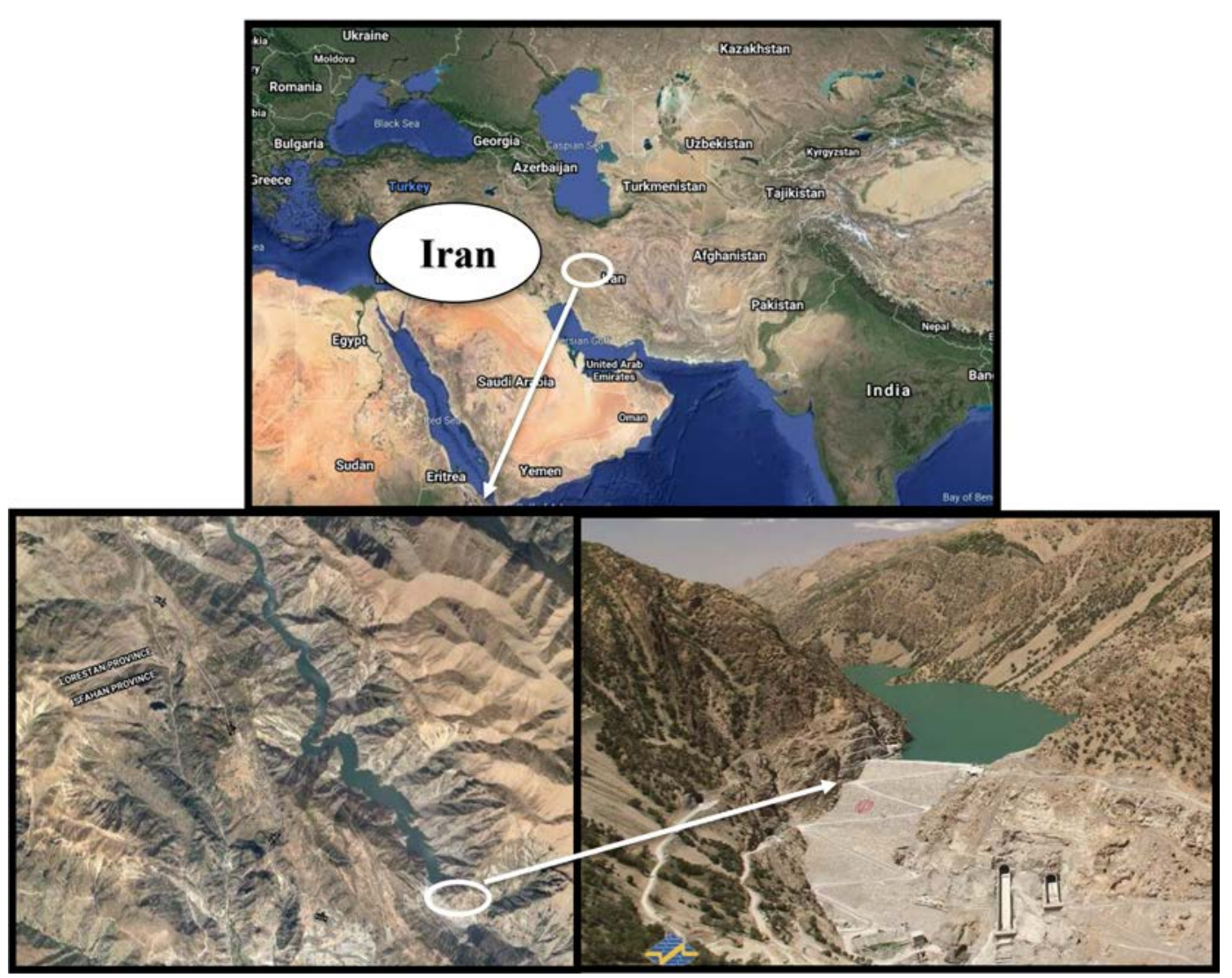

Figure 1. Location and view of the body of Rudbar dam.

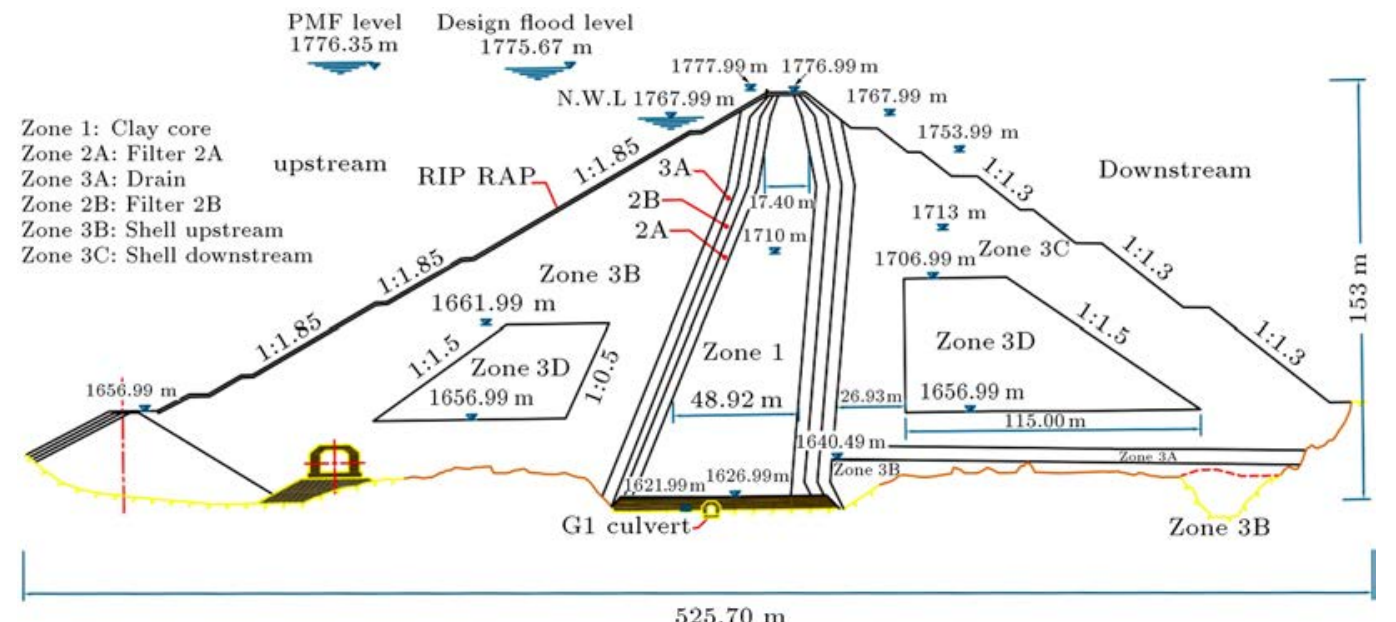

Figure 2. The critical section, different levels, and zones of different parts of Rudbar dam.

modeling were extracted from laboratory experiments of soil mechanic in a fine and coarse materials of the dam. Table 2 presents the initial values of the MohrCoulomb model parameters including elastic modulus $(E)$, Poisson ratio $(\nu)$, friction of soil $(C)$, friction angle $(\phi)$, dilation angel and stress $(\psi)$, and hydraulic conductivity $(k)$ in different conditions for different dam areas. As the inputs to the software, these values were used for initial calculations.

\subsection{Back analysis}

Machine learning methods and data mining are other techniques employed in this study. With their great capability to handle the nonlinear database, machine learning methods have been proven powerful in dam engineering. Inverse analysis is one of these methods [3032]. Back analysis is an effective tool for investigating and modifying soil parameters. The obtained results from this analysis can be used for project evaluation, 


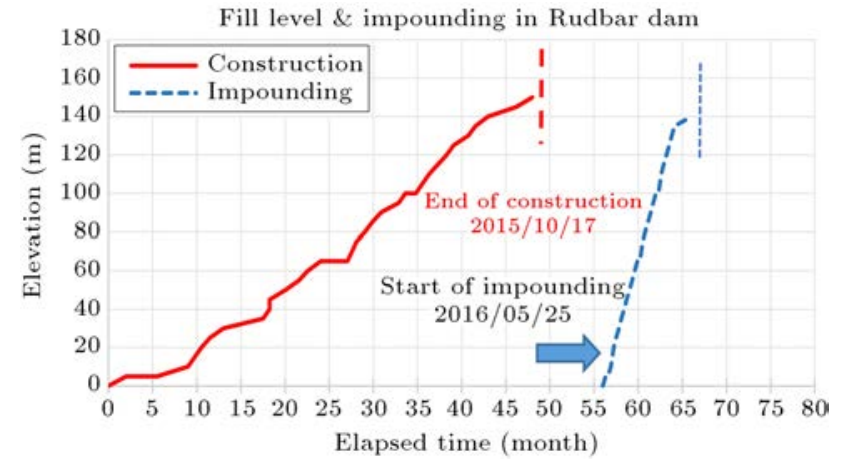

Figure 3. Construction and impounding periods of Rudbar dam.

Table 1. Technical characteristics of the Rudbar dam and its reservoir [25].

\begin{tabular}{ll}
\hline \multicolumn{1}{c}{ Dam detail } & \multicolumn{1}{c}{ Value } \\
\hline $\begin{array}{l}\text { Height from bed to crest } \\
\text { Largest cross-section }\end{array}$ & $153 \mathrm{~m}$ \\
Width of the dam crest & $15 \mathrm{~m}$ \\
Length of the dam crest & $185 \mathrm{~m}$ \\
Dam crest elevation a.s.l & $1765 \mathrm{~m}$ \\
Normal water level a.s.l & $1756 \mathrm{~m}$ \\
Area of reservoir length & $20 \mathrm{~km}$ \\
Dam body material volume & $4.596 \times 10^{6} \mathrm{~m}^{3}$ \\
Volume reservoir & $228 \times 10^{6} \mathrm{~m}^{3}$ \\
\hline
\end{tabular}

and their designs that are similar in structure can also be improved [33]. Back analysis of data from instrumentation and monitoring of dams at the time of construction and operation, in addition to almost sure evaluation of geotechnical parameters, determines the stability status of the structure. In general, back analysis is a method for predicting the parameters governing a system by analyzing the output behavior of that system. Overall, back analysis methods are classified in two inverse and direct types [34].

Generally, to conduct a back analysis, two steps are required. First, in the stress analysis method, the numerical methods are employed to determine the stress, strain, and displacement distribution for the problem in question. Second, an appropriate algorithm of optimization is employed that can minimize the difference between the values measured in situ and the data obtained from the stress analysis [35]. This difference is expressed in the form of an error function. In this paper, a direct displacement-based method was utilized. One of the great advantages of the direct displacement method is its easy application to nonlinear problems and elastoplastic materials. Although this method requires much time for computation and a great deal of repetition in computing, it is still widely used in geotechnical engineering [36]. In general, there are three different algorithms for direct back analysis: the invert method, multivariate method, and alternating univariate methods [37]. In the univariate method, only one parameter at each step changes and the other parameters will remain constant. In the next step, after optimizing one parameter, another parameter is changed, while the other parameters are kept constant. This process continues until all optimal values of all parameters are obtained. In the multivariate method, unlike the invert method, parameter optimization is performed simultaneously. Therefore, the model with the least error is considered as the optimal model, and the parameters corresponding to it are called the optimal parameters. The alternating univariate method is the extended form of the univariate method with enhanced functions. In this method, upon finding the optimal values of the parameters according to the invert method, all parameters are simultaneously changed. Simultaneous change of parameters continues until the target function reaches the desired value.

In other words, the back analysis can be described as obtaining the initial parameters when conducting soil mechanics experiments on the borrow materials. These materials are transported to the site of the dam and crushed into layers with certain thickness until reaching a certain density. This is the reason why it is necessary to obtain the actual parameters of the materials when they are in the dam body using the instrumentation and back analysis results. In this respect, the main input parameters to the software

Table 2. List of properties of materials for numerical analysis (primary parameters) [25].

\begin{tabular}{|c|c|c|c|c|c|c|c|c|}
\hline \multirow{2}{*}{$\begin{array}{c}\text { Material } \\
\text { descriptions }\end{array}$} & \multirow{2}{*}{$\begin{array}{c}k \\
(\mathrm{~cm} / \mathrm{s})\end{array}$} & \multirow{2}{*}{$\phi^{\circ}$} & \multirow{2}{*}{$\begin{array}{c}C \\
(\mathrm{kPa})\end{array}$} & \multicolumn{2}{|c|}{$\gamma\left(\mathrm{kN} / \mathrm{m}^{3}\right)$} & \multirow{2}{*}{$\begin{array}{c}E \\
(\mathrm{MPa})\end{array}$} & \multirow{2}{*}{$\psi^{\circ}$} & \multirow{2}{*}{$\nu$} \\
\hline & & & & Sat & Dry & & & \\
\hline Core & $1 \times 10^{-7}$ & 25 & 50 & 23.4 & 21.5 & 35 & 0 & 0.35 \\
\hline Filter 3 & $5 \times 10^{-4}$ & 39 & 0 & 21.9 & 19 & 70 & $7-10$ & 0.33 \\
\hline Filter 2 & $5 \times 10^{-2}$ & 39 & 0 & 22.2 & 19.5 & 70 & $7-10$ & 0.30 \\
\hline Drain & 1 & 45 & 0 & 23.2 & 21 & 70 & $7-10$ & 0.25 \\
\hline Shell upstream & $1 \times 10^{-1}$ & 45 & 0 & 23.5 & 21.5 & 70 & $3-5$ & 0.25 \\
\hline Downstream & $1 \times 10^{-1}$ & 45 & 0 & 23.2 & 21 & 70 & $3-5$ & 0.25 \\
\hline
\end{tabular}




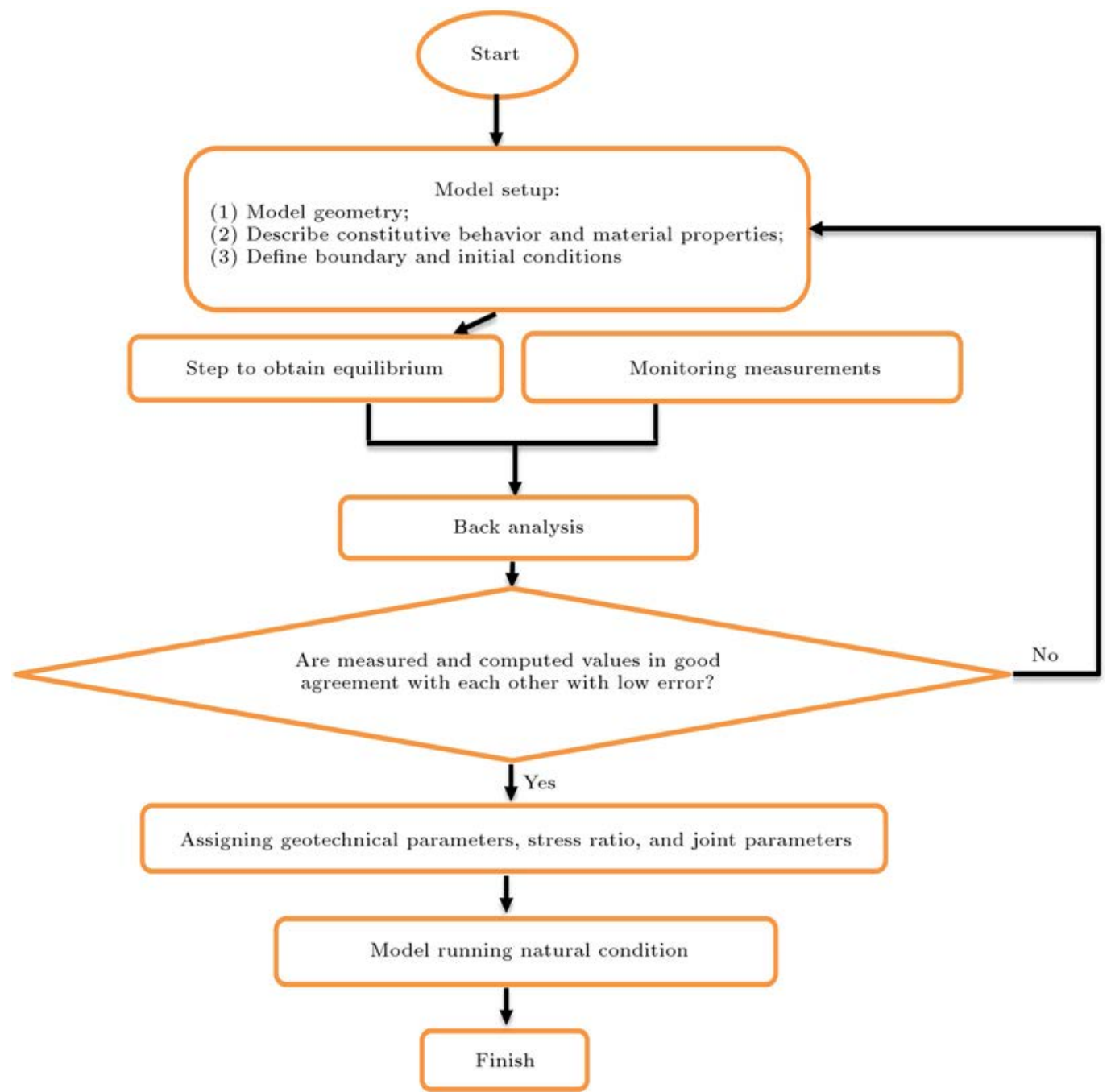

Figure 4. Solution algorithms for back analysis.

must be changed according to the actual dam behavior obtained from the information of instrumentation to the extent that the actual behavior of the dam is created in the model. The solution process algorithm is illustrated in Figure 4.

Due to the availability of the displacement values measured by the tube of the deflectometer installed in the dam body, the displacement-based direct back analysis method was employed for back analysis of Rudbar dam to determine the optimal material parameters. This method functions based on the optimization of the mechanical parameters of the materials through the trial-and-error method. To this end, the error function (Eq. (1)) was written in the FISH programming language in order to minimize the difference between the displacements measured by the deflectometers tubes and those calculated by numerical modeling.

$$
\in(P)=\sqrt{\frac{1}{n} \sum_{i=1}^{n}\left(\frac{u_{i}^{m}(p)-u_{i}}{u_{i}}\right)^{2}},
$$

where $n$ is the number of measurement points, $i=$ $1,2, \cdots, n ; u_{i}$ and $u_{i}^{m}(p)$ are the measured and calculated values of the displacements, respectively, through numerical analysis at the corresponding points. The value of $u_{i}(p)$ depends on the unknown parameters of the model that are aggregated in the vector $P$. Before performing the back analysis, it is recommended that the results of the instrumentation be processed and the incorrect displacements caused by error of reading or improper performance of instrumentation be removed. In conventional analysis, a mechanical model capable of introducing the mechanical behavior of a structure is taken into consideration. Then, the values of mechanical constants are determined using field and laboratory experiments. Based on the relationship between the values of the back analysis, the field measurements (instrumentation), and methods for design and execution, it can be concluded that back analysis is completely different from the conventional analysis.

It is assumed that a typical analysis of a mechan- 


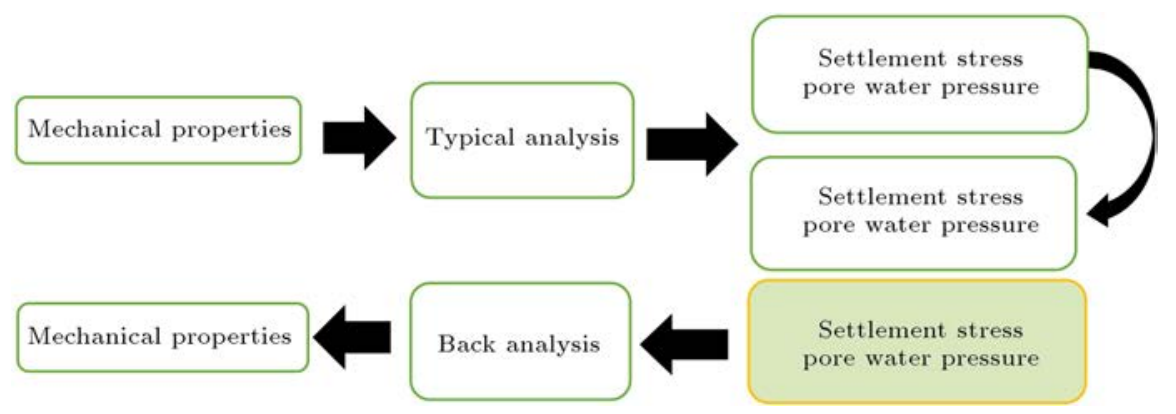

Figure 5. Typical analysis and back analysis.

ical model can introduce the mechanical behavior of a structure. Then, the values of mechanical constants are determined using field experiments and laboratory tests. The input data of the typical analysis, presented in Figure 5, are employed to calculate settlement values, pore water pressure, and stress.

\subsection{Numerical analysis and modeling}

Rudbar dam was modeled using FLAC 2D software, which is based on the finite difference method. In addition, Mohr-Coulomb elastoplastic behavioral model was used to investigate the materials used in the body. As one of the most well-known soil behavioral models, this model contains most of the basic soil parameters such as plastic and elastic that make it suitable for modeling most soil behavioral modes. In this respect, this model has been employed in a number of researches due to its simplicity and non-requirement for multiple parameters.

The parameters used in this behavioral model include cohesion $(C)$, friction angle $(\phi)$, elastic modulus $(E)$, Poisson's ratio $(\nu)$, unit weight $(\gamma)$, and coefficient of permeability $(k)$. Table 2 represents initial values of the mentioned parameters.

There is a criterion in the Mohr-Coulomb behavioral model that defines the boundary between elastic and plastic deformations, and the behavior of materials after entering the plastic zone is quite different from that before crossing this boundary. In this behavioral model, the failure envelope is obtained by the wellknown Mohr-Coulomb criterion, which is a function of shear failure $\left(f_{s}\right)$, considering the tensile failure criterion $\left(f_{t}\right)$. The failure level of $f_{s}$ and $f_{t}$ is obtained through Eqs. (2)-(4), as shown in the following:

$$
\begin{aligned}
& f_{s}=\sigma_{1}-\sigma_{3} N_{\phi}+2 C \sqrt{N_{\phi}}, \\
& f_{t}=\sigma_{1}-\sigma_{3} .
\end{aligned}
$$

$N_{\phi}$ can be measured as in the following:

$$
N_{\phi}=\frac{1+\sin \phi}{1-\sin \phi}
$$

where $C$ is the adhesion, $\phi$ is the angle of internal friction, and $\sigma_{1}$ and $\sigma_{3}$ are the tensile strengths.

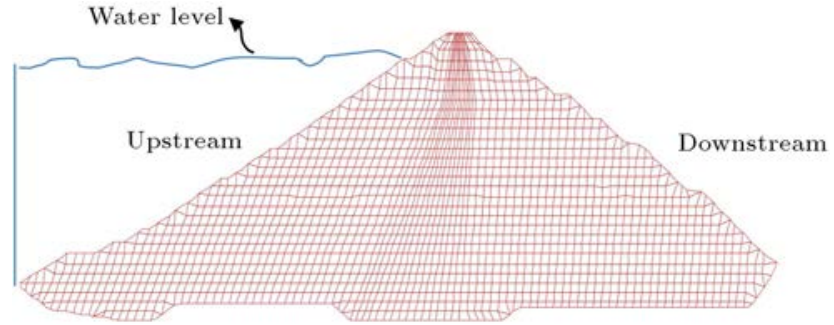

Figure 6. Mesh generation of Rudbar dam body at the critical cross-section.

The parameters of the Mohr-Coulomb behavioral model are $\phi$ and $C$, which are related to the plastic mechanism of the model, as well as $E$ and $\nu$, which are related to the elastic mechanism of the model. These parameters are determined by ordinary and common experiments such as triaxial tests. A simulation of a drained triaxial test with the Mohr-Coulomb model reveals that the behavior of the model before the failure is controlled by $E$ and $\nu$ parameters, and the maximum shear strength is controlled by $\phi$ and $C$ parameters.

Rudbar dam was modeled in 31 layers, and the height of each layer was $5 \mathrm{~m}$. An element grid of $97 \times 31$ was used for modeling the dam body. In the first step, the quadrilateral elements with four nodes with a length-to-width ratio of approximately 1 were considered in producing the mesh. After designing the total grid of the dam body, extra elements were removed, and the optimal mesh model of the critical section was obtained based on Figure 6 . In the second step, after creating the dam model geometry, the boundary and initial conditions were applied to the model so that the lateral boundaries could be displaced, and at the lower boundary, the horizontal and vertical displacements were assumed to be zero.

In the third step, for bedded modeling and investigating both consolidation phenomenon and pore water pressure on the dam, first, the timing plan of the dam construction was determined based on the actual time of dam body embankment that took more than 1440 days. Then, the total required construction time was given to the software for each of the 31 layers of the body. Next, the first layer of the dam body was created, and by performing mechanical computational 
steps, the unbalanced force reached zero. Followed by this step, all layers of the dam body were constructed, and construction of the dam in the model software was simulated and then, impoundment of Rudbar dam at seven stages, each stage with the height of $20 \mathrm{~m}$ (which lasted for 10 months), was modeled. The maximum water stage in the reservoir was recorded as $141 \mathrm{~m}$. To simulate the dam impoundment, the mechanical force resulting from the weight of the reservoir water was applied to the upstream crust and then, the corresponding hydrostatic pressure of the reservoir water was applied to the same area and the model was run until the allotted time.

It should be noted that due to the very low permeability of the rock bed and construction of a concrete slab under the core as well as the partial settlement at the time of construction $(7 \mathrm{~cm})$, the modeling of foundation was ignored.

\section{Results and discussion}

In this section, first, the contours obtained from modeling the pore water pressure, vertical and horizontal stress at the end of construction and impounding are presented in Figures 7-12.

\subsection{Pore water pressure}

With regard to embankment dams, monitoring the pore water pressure gains significance since it is the main
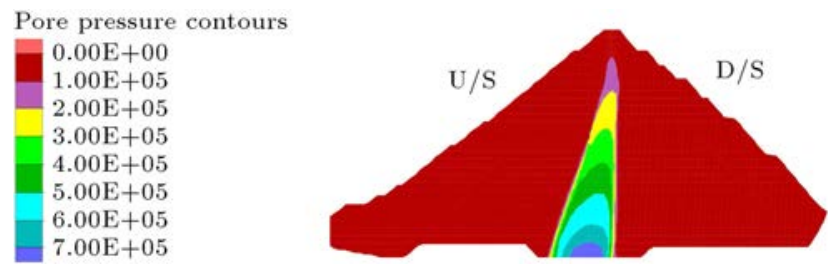

Figure 7. Pore water pressure at the end of construction (body height $155 \mathrm{~m}$ ) (unit: $\mathrm{Pa}$ ).

Pore pressure contours
$0.00 \mathrm{E}+00$
$2.50 \mathrm{E}+05$
$5.00 \mathrm{E}+05$
$7.50 \mathrm{E}+05$
$1.00 \mathrm{E}+06$
$1.25 \mathrm{E}+06$
$1.50 \mathrm{E}+06$

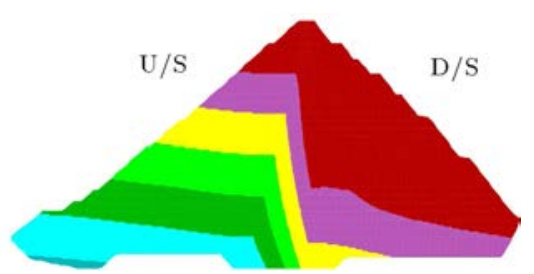

Figure 8. Pore water pressure at steady-state (unit: Pa).

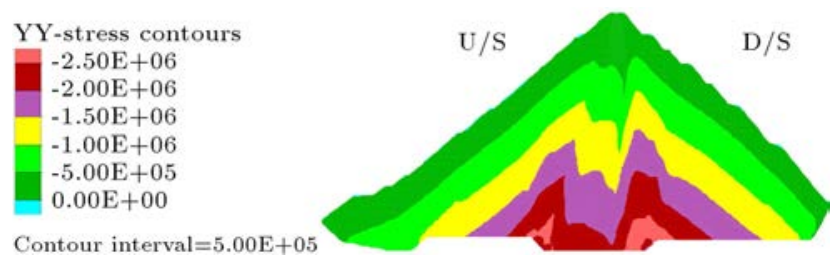

Figure 9. Vertical stress construction at $155 \mathrm{~m}$ height (unit: $\mathrm{Pa}$ ).
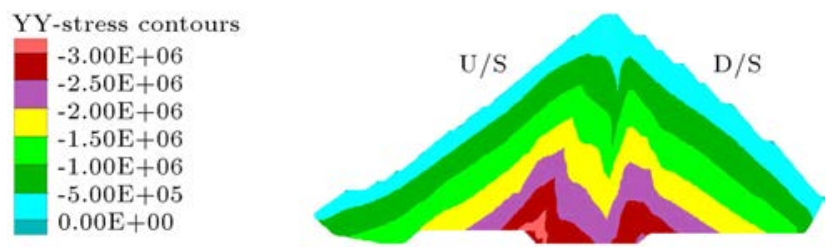

Figure 10. Vertical stress of initial impounding to normal levels (unit: $\mathrm{Pa}$ ).
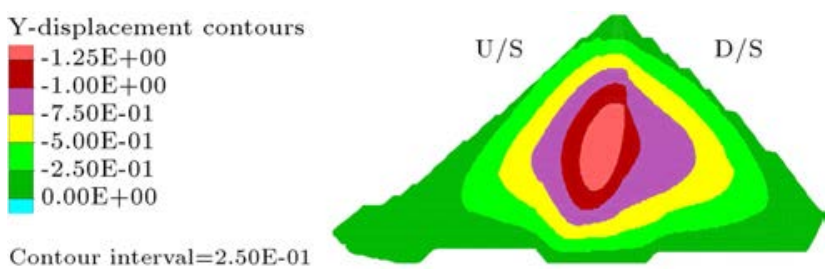

Figure 11. Settlement construction at $155 \mathrm{~m}$ height (unit: $\mathrm{m}$ ).

Y-displacement contours
$-1.25 \mathrm{E}+00$
$-1.00 \mathrm{E}+00$
$-7.50 \mathrm{E}-01$
$-5.00 \mathrm{E}-01$
$-2.50 \mathrm{E}-01$
$0.00 \mathrm{E}+00$

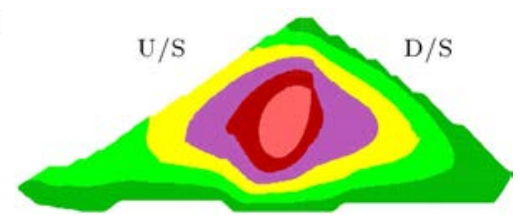

Figure 12. Settlement initial impounding to normal levels (unit: $\mathrm{m}$ ).

indicator of internal erosion and seepage problems that plays a significant role in the stability of geotechnical works [38].

Installed piezometers at the core of the Rudbar dam were placed at six different levels. This study emphasizes the most acute pore water pressure or the most pore water pressure recorded by piezometers at the core of the dam located at $1615 \mathrm{~m}$. The electrical piezometers installed at this level consist of 7 piezometers where piezometer EP16 and EP19 are obstructed and their results are not available. Figure 13(a) shows the pore water pressure diagram of electric piezometers at a level of $1615 \mathrm{~m}$. As shown earlier, as the height of the dam increases, the pore water pressure also increases. Another significant note is that at the time of construction, the middle piezometers of the core dam record much more water pressure than lateral piezometers due to greater water pressure at the middle of the core than the lateral section of the core.

\subsection{Comparison of pore water pressure measured by instrumentation with a numerical model}

In this study, because of the highest pore water pressure recorded at the bottom of the core, i.e., Level $1615 \mathrm{~m}$ is recorded by the instrumentation, the comparison between instrumentation results and the numerical modeling is made at this level. A comparison between the pore water pressure measured by the 


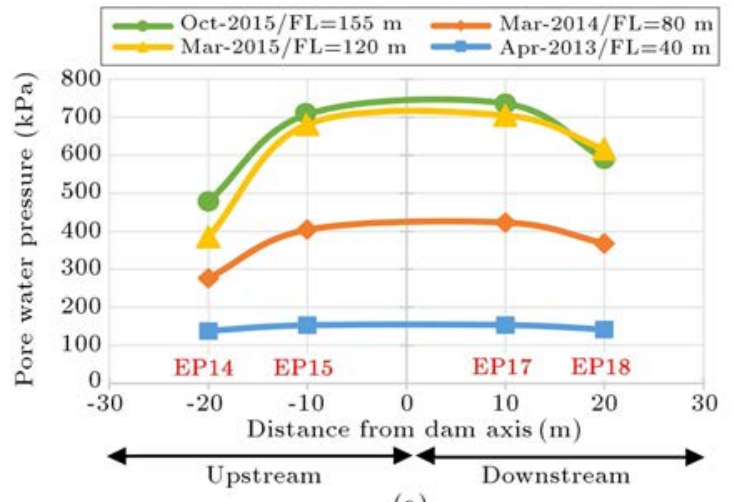

(a)

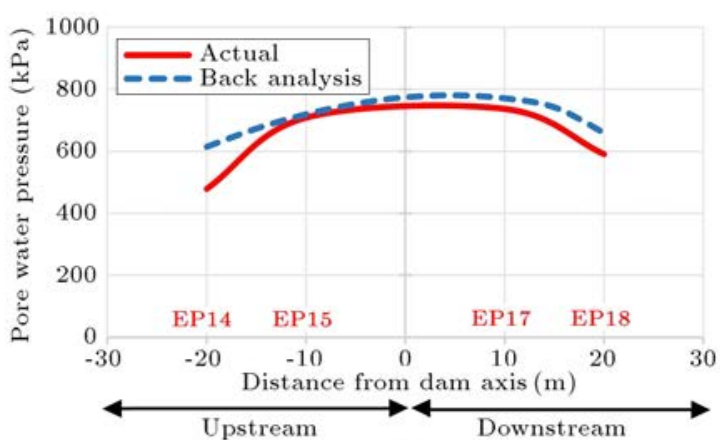

(b)

Figure 13. Pore water pressure changes at the time of construction (a) and comparison of the pore water pressure measured by instrumentation and numerical model at the end of construction (b) at level of $1615 \mathrm{~m}$.

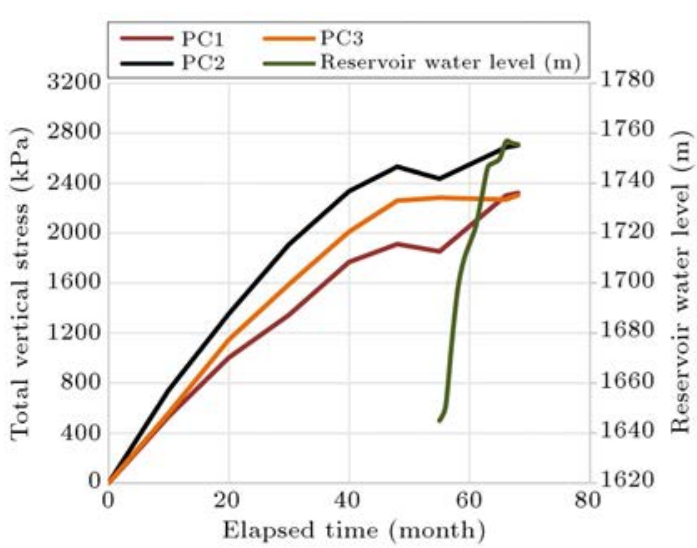

(a)

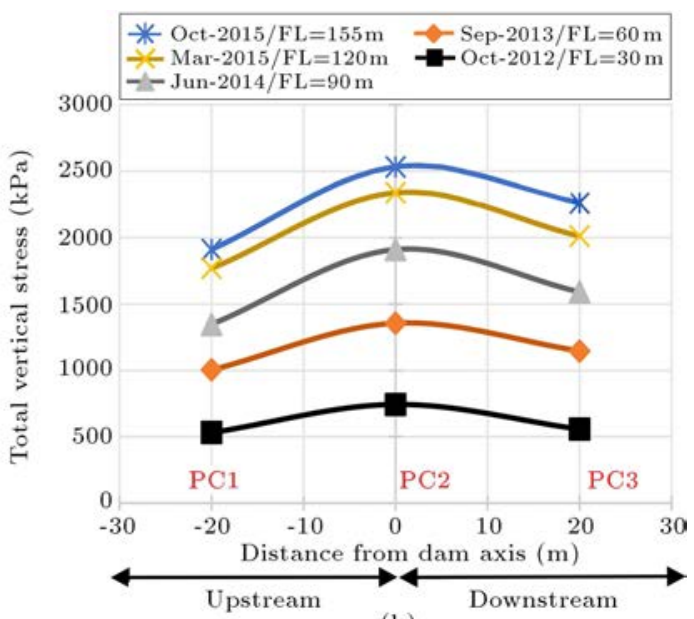

(b)

Figure 14. (a) Total vertical stress of core dam at the time of construction. (b) Changes in the total vertical stress at level of $1615 \mathrm{~m}$.

instrumentation and the numerical model at the end of the dam body construction is shown in Figure 13(b).

As given in Figure 13(b), the maximum pore water pressure values for instrumentation are determined as $736 \mathrm{kPa}$ and $780 \mathrm{kPa}$ at the end of construction and in the numerical modeling, respectively. Good agreement exists between the results. The numerical analysis and instrumentation suggest that the maximum pore water pressure occurs at the center of the core, while the minimum pressure during construction and end of construction is recorded in upstream and downstream of the core.

\subsection{Total vertical stress}

Manometers that measure total stress (vertical and horizontal) were installed at the core of the dam at five different levels with three clusters that measure the soil pressure in three directions: vertical, horizontal, and in accordance with the core axis. This study focuses on the most critical level in the dam body, the $1615 \mathrm{~m}$ level where $\mathrm{PC} 1, \mathrm{PC} 2$, and $\mathrm{PC} 3$ pressure cells are installed at this level and the following measurements of these pressure cells are presented. Pressure cells that have been horizontally installed, measure stress in the vertical direction $\left(\sigma_{Y}\right)$; those that are parallel to the dam axis measure stress along the $X$-axis $\left(\sigma_{X}\right)$, and those that have been vertically installed on the dam axis measure stress along the $Z$-axis $\left(\sigma_{Z}\right)$.

Figure 14(a) shows the measurement of total vertical stress at the core of the dam at the end of construction at different embankment levels. As can be seen, the vertical stress at the center of the core is higher than that on the lateral side and by increasing the height of the dam embankment, vertical stress increases.

Figure 14(b) shows changes to pressure cells at the end of construction and impounding at a level of $1615 \mathrm{~m}$.

\subsection{Comparison of the total vertical stress measured by the instrumentation with the numerical model}

Considering that the highest vertical stress is recorded at the bottom of the core, i.e., the level $1615 \mathrm{~m}$ by 


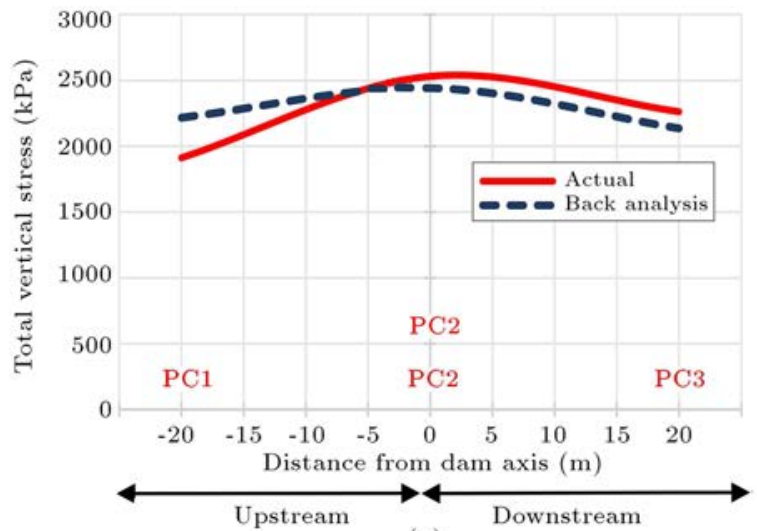

(a)

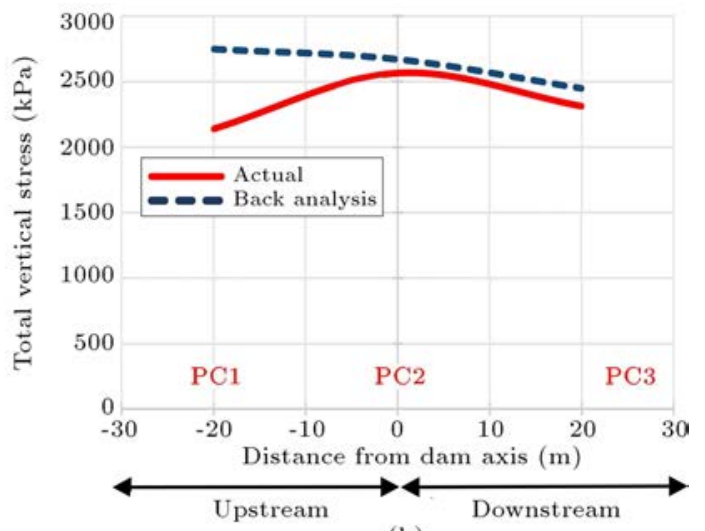

(b)

Figure 15. Comparing the total vertical stress measured by the instrumentation and numerical modeling at the end of construction (a) and at the end of impounding (b) at level of $1615 \mathrm{~m}$.

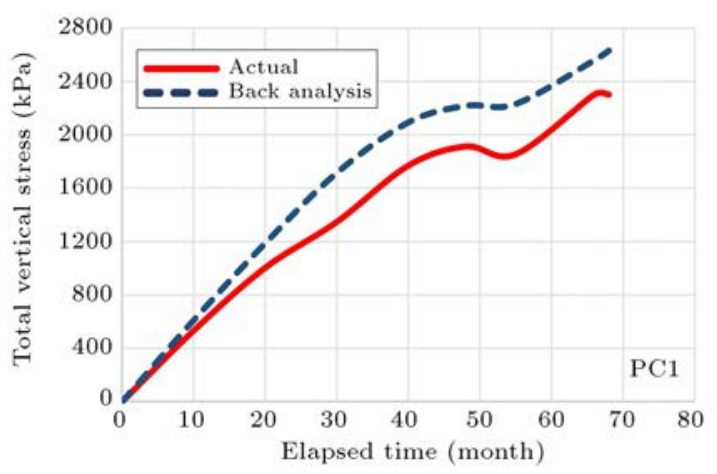

(a)

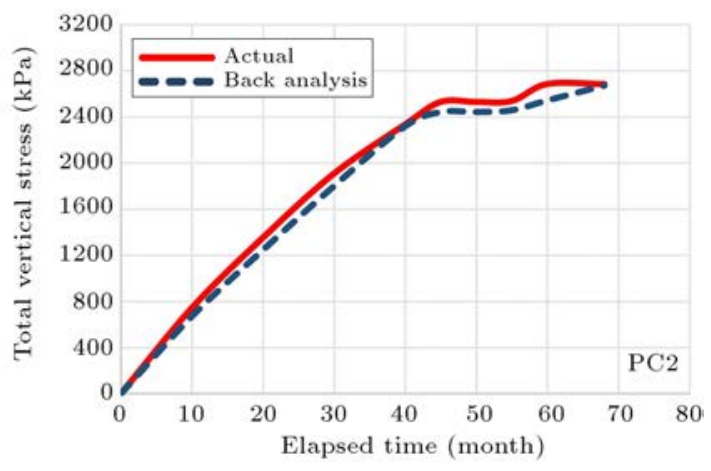

(b)

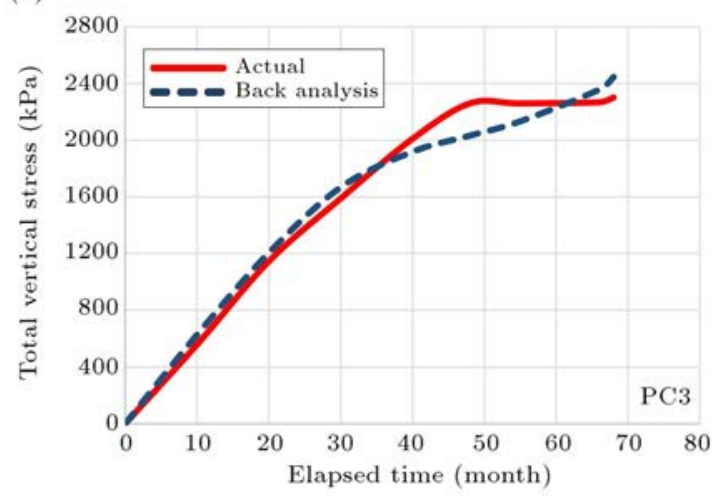

(c)

Figure 16. Changes in the total vertical stress measured by instrumentation and numerical model in the pressure cells PC1, PC2, PC3 at level of $1615 \mathrm{~m}$.

the instrumentation, a comparison between the instrumentation results and numerical model is performed at this level. Figure 15(a) shows the verification of the vertical stress measured by the instrumentation and the numerical model at the end of construction. The maximum vertical stress of instrumentation at the end of construction and in the numerical model is obtained as $2530 \mathrm{kPa}$ and $2442 \mathrm{kPa}$, respectively. Figure 15(a) points to the good convergence. Accordingly, the maximum vertical stress occurs at the center of the core, and the results of the numerical model and instrumentation indicate that the least stress occurs in the upstream of the core during construction and downstream of the core at the end of construction.

In this research paper, the vertical stress of impounding stage is presented. Figure 15(b) shows a comparison between the results of instrumentation and the numerical model. Figure 16 presents the vertical stress variations of $\mathrm{PC} 1, \mathrm{PC} 2$, and $\mathrm{PC} 3$ cell pressures derived from a numerical model and instrumentation during construction and impounding.

According to Figure 16(a), there is a slight differ- 
ence between the instrumentation and the numerical model, because there is less density around the cell than other parts of the core to prevent damage. Therefore, the rigidity of other parts is greater than that of the surrounding of the cell, but changes in the cell pressure PC2 and PC3 are in good agreement, as shown earlier.

\subsection{Evaluation of arching ratio}

When the arching ratio is larger, arching does not occur many times in that location. However, when the arching ratio is smaller, arching occurs quite a lot in that location. Increase in the arching ratio value reduces the soil core pressure with respect to the hydrostatic pressure, resulting in cracks appearing on the core. This phenomenon is known as hydraulic failure [39]. Eq. (5) shows the existing relation for the arching ratio:

$$
\mathrm{Ar}=\frac{r_{u}}{R_{u}}=\frac{\sigma_{p c}}{\gamma \cdot h}
$$

where $\gamma$ is the unit weight column of soil above the instrumentation, $h$ the height of the soil column above the instrumentation, and $\sigma_{p c}$ the total stress measured by instrumentation.

In Figure 17(a), the arching ratio at the end of construction and impounding is shown at level $1615 \mathrm{~m}$. As it is known, at the end of construction, the lowest arching ratio was recorded 0.53 at upstream of the core, while at the end of the initial impounding, the highest increase was observed at upstream of the core; this finding points to the effect of impounding on the arching ratio.

\subsection{Comparison of arching ratio of the} instrumentation with the numerical model The comparison of arching ratios in Figure 17(b) shows that the maximum and minimum of the arching ratio obtained from numerical modeling are 0.68 and 0.59 , respectively.

After initial impounding, it should be investigated whether the hydraulic failure phenomenon has occurred

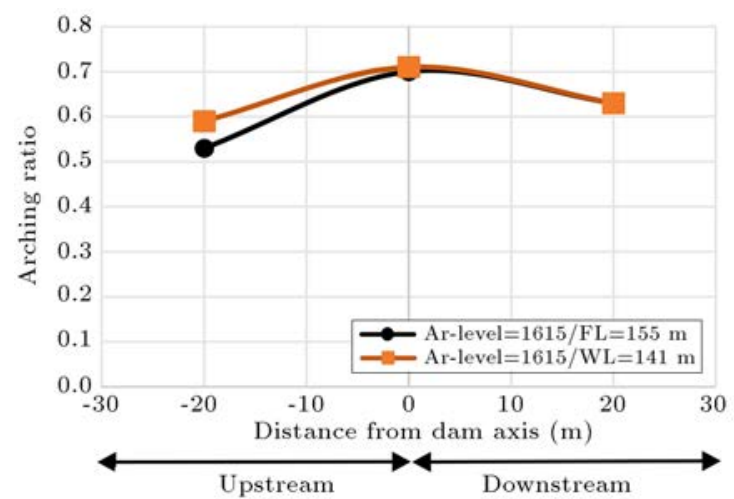

(a) in the dam body or not. One solution is to obtain the arching ratio. After impounding, due to the water pressure on the upstream of the dam, the arching ratio must be checked because if the value of this ratio is small at the end of the construction, the possibility of arching to occur is very high. Of course, in Rudbar dam, the lowest value of arching ratio was 0.53 at the end of construction and it reached 0.59 in impounding, which not only not declined but also increased.

\subsection{Settlement}

At Rudbar dam, three inclinometers (settlement tubes) are installed at the upstream center of the core and downstream, which measure the settlement in these sections. Figure 18 shows the settlement changes on the core (IN2) at nine intervals and different heights at the time of construction and initial impounding of the dam. Per official notice, the dam construction was completed in October 2012; the maximum settlement was $137.5 \mathrm{~cm}$ which occurred at the core of the dam in this period. The initial impounding began in March 2016 and in this period, the maximum settlement in the dam was recorded as $156.9 \mathrm{~cm}$ on the inclinometers critical sections.

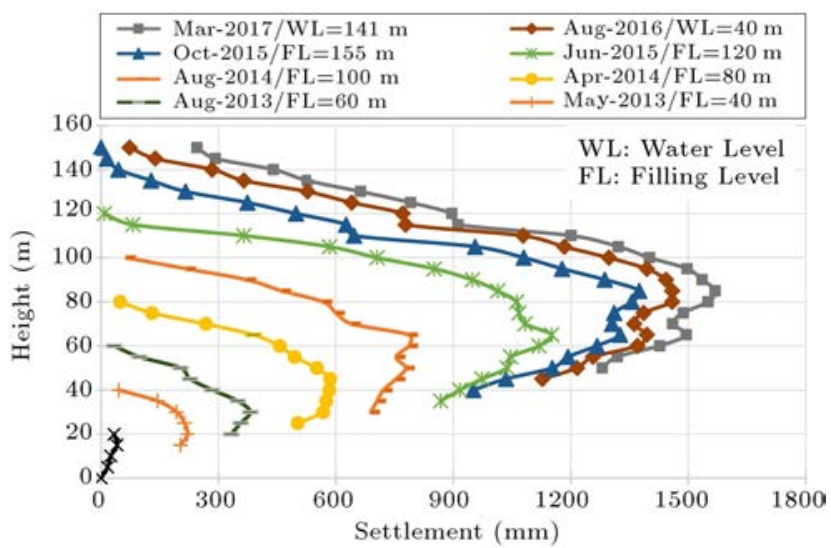

Figure 18. Core settlement obtained from IN2 along with dam height at different times.

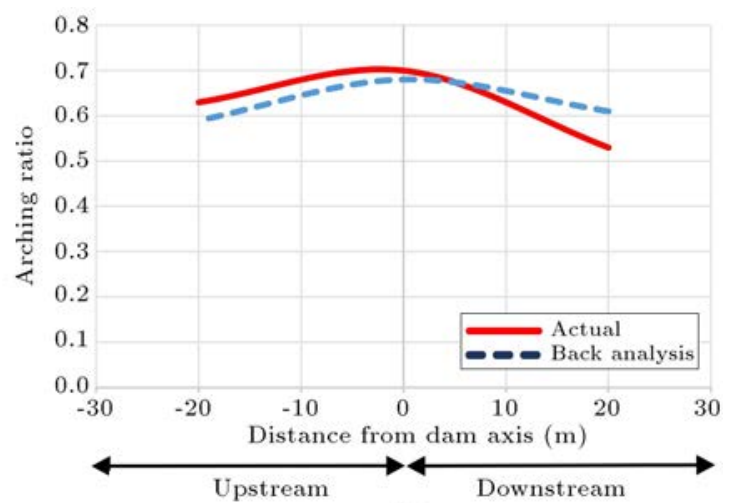

(b)

Figure 17. The arching ratio of core of the dam at the end of construction and initial impounding; comparison of the arching ratio measured by instrumentation and numerical model at the end of construction at level of $1615 \mathrm{~m}$. 


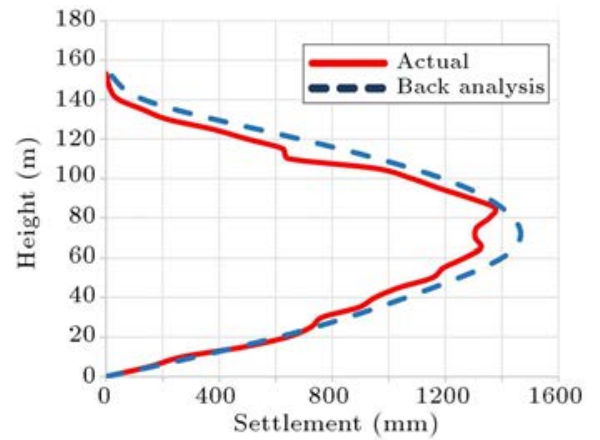

(a)

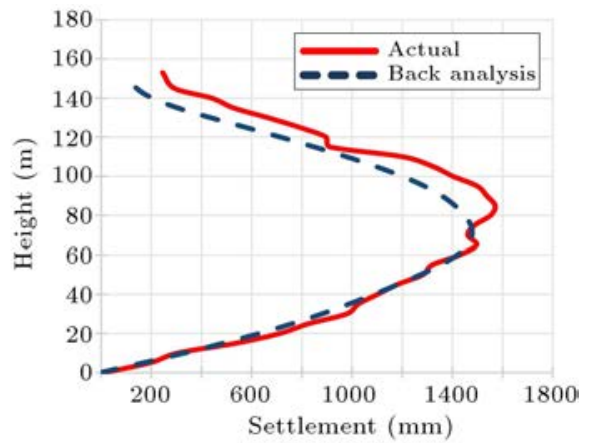

(b)

Figure 19. Comparison of the core settlement obtained from instrumentation and numerical model at the end of construction and initial impounding.

Table 3. Final parameters in the back analysis (actual parameters).

\begin{tabular}{|c|c|c|c|c|c|c|c|c|}
\hline \multirow{2}{*}{$\begin{array}{c}\text { Material } \\
\text { descriptions }\end{array}$} & \multirow{2}{*}{$\begin{array}{c}k \\
(\mathrm{~cm} / \mathrm{s})\end{array}$} & \multirow{2}{*}{$\phi^{\circ}$} & \multirow{2}{*}{$\begin{array}{c}C \\
(\mathrm{kPa})\end{array}$} & \multicolumn{2}{|c|}{$\gamma\left(\mathrm{kN} / \mathrm{m}^{\mathbf{3}}\right)$} & \multirow{2}{*}{$\begin{array}{c}E \\
(\mathrm{MPa})\end{array}$} & \multirow{2}{*}{$\psi$} & \multirow{2}{*}{$\nu$} \\
\hline & & & & Sat & Dry & & & \\
\hline Core & $1 \times 10^{-13}$ & 28 & 50 & 23.5 & 21.5 & 43 & 0 & 0.37 \\
\hline Filter 3 & $5 \times 10^{-10}$ & 40 & 0 & 21.9 & 20 & 70 & 9 & 0.37 \\
\hline Filter 2 & $5 \times 10^{-8}$ & 40 & 0 & 22.2 & 20.5 & 70 & 9 & 0.30 \\
\hline Drain & $1 \times 10^{-3}$ & 46 & 0 & 23.2 & 22 & 70 & 9 & 0.37 \\
\hline Upstream & $1 \times 10^{-3}$ & 46 & 0 & 23.5 & 22.5 & 70 & 5 & 0.25 \\
\hline Downstream & $1 \times 10^{-13}$ & 46 & 0 & 23.2 & 22 & 70 & 5 & 0.25 \\
\hline
\end{tabular}

\subsection{Comparison of settlements obtained from instrumentation measurements and numerical model}

One of the parameters for stability analysis of earth and rockfill dams is the experience of settlement in earth rockfill dams during construction [24]. Figure 19 makes a comparison concerning the settlement occurring at the center of the core at the end of construction (a) and initial impounding (b). The maximum settlement recorded by the instrumentation and modeling at the end of the construction was as $137.5 \mathrm{~cm}$ and $146 / 5 \mathrm{~cm}$, respectively. The mentioned settlement after the impounding in instrumentation and modeling was obtained as $156.9 \mathrm{~cm}$ and $147.8 \mathrm{~cm}$, respectively.

\subsection{Results of back analysis}

In order to validate and verify such parameters as pore water pressure and vertical and horizontal stresses, the actual geotechnical parameters of the dam body were obtained using the back analysis method. Table 3 presents the values of the final parameters obtained from the back analysis.

\subsection{Comparison of actual geotechnical parameters obtained from back analysis with initial parameters}

Table 3 gives the final parameters obtained by back analysis and some parameters were presented as a bar graph in this paper. Figure 20(a) shows Poisson's ratio and Figure 20(b) shows the friction angle in different dam conditions. Figure 20(a) of the core, Filter 3, and drain experienced an increase in the final condition, while no change or variation was detected in the other parts. However, in Figure 20(b), all of the dam sections changed in the final condition.

Figure 20(c) shows the dry unit weight of the core that remains constant, while all the other parts increase in the final condition.

\section{Conclusion}

The main objectives of the present study are as follows:

(a) Providing a general assessment of the performance of the dam at the time of construction and initial impounding using the data obtained from the instrumentation of the Rudbar rockfill earthen dam;

(b) Reaching actual geotechnical parameters in the body of the Rudbar dam at the end of the construction through the back analysis method.

The results of the present study are as follows:

1. The highest settlement rate for Rudbar dam was observed at the core and height of $85 \mathrm{~m}$ from the floor. Rudbar dam experienced $87 \%$ of its total 


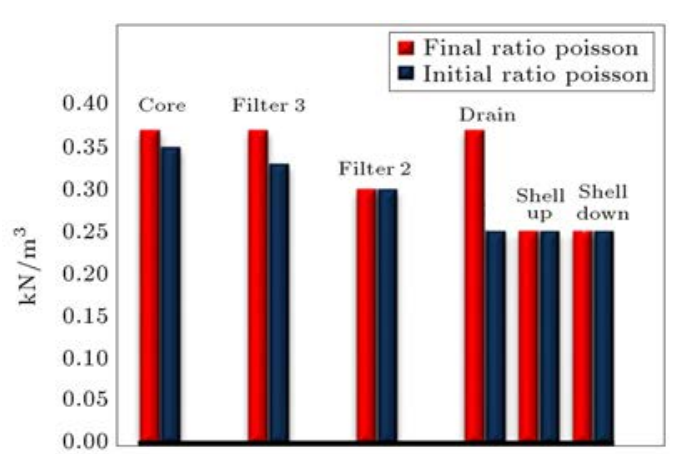

(a)

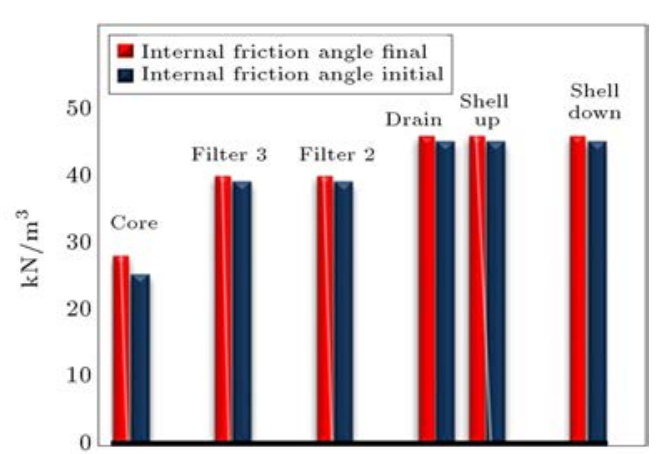

(b)

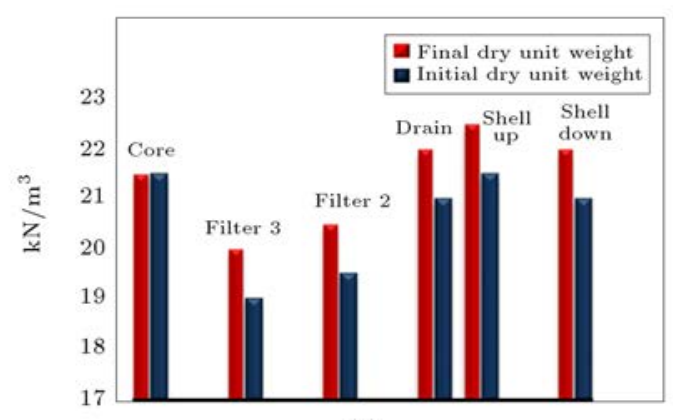

(c)

Figure 20. Comparison of Poison's ratio, friction angle, and dry unit weight in the initial conditions obtained from the back analysis (final).

settlement at the end of construction. In addition, the maximum settlement in this dam at the end of construction was $1.37 \mathrm{~m}$, which was less than $1 \%$ of the dam height. In comparison with the settlement in other dams, such as Alavian dam with the height of $80 \mathrm{~m}$ and settlement of $1.30 \mathrm{~m}$ (about $1.6 \%$ of the body height) and Gavoshan dam with the height of $123 \mathrm{~m}$ and settlement of $2.7 \mathrm{~m}$ (about $2.1 \%$ of the body height), the settlement of the Rudbar dam was acceptable;

2. The maximum pore water pressure was observed at the center of the core at the end of the construction while the lateral part of the core did not tolerate the pressure much. At the impounding stage, the maximum pore water pressure was recorded in the upstream of the dam, mainly because of its vicinity to the upstream of the core;

3. The dam was constructed of 31 layers and the impounding was appropriate in seven states. Of note, the assumption of fewer layers existing at the time of construction would change the results of pore water pressure due to the thick layers placed and their sudden weight addition. Placing layers with the thickness more than $8 \mathrm{~m}$ would cause extra pore water pressure at the initial stage of construction. In this regard, to analyze the earth and rockfill dams, it is suggested that the number of layers be considered in accordance with the thickness of $5 \mathrm{~m}$;

4. Arching ratio was one of the criteria used for controlling hydraulic failure in earth rockfill dams. The arching ratio of the critical level of the Rudbar dam body was 0.53-1.6 which was in good agreement with the arching ratios observed in large dams such as Asvatvan (Norway), Karkheh, and Ardak dams with the arching ratios of $0.33-0.9,0.47-$ 0.75 , and 0.63, respectively. After impounding the Rudbar dam, the arching ratio rate increased and the arching decreased;

5. According to the results, the back analysis method was a suitable method for determining the actual parameters of earth and rockfill dams;

6. Based on the evaluation results of instrumentation system of the Rudbar dam body, it can be concluded that both the instrumentation system and the measuring equipment of this dam quantitatively and qualitatively enjoyed good health to continue measuring and recording the instrumentation data;

7. According to the values obtained from back analysis, the utmost change was observed in the dry unit weight parameter, and all the parameters followed a constant or increasing trend.

Generally, in case one does not apply back analysis for the geotechnical parameters of the dam, there will 
be no real assessment or understanding of the actual geotechnical parameters of the dam body. However, this study could present a proper view of the actual geotechnical parameters of the Rudbar dam body.

\section{References}

1. Blind, H. "Teh safety of dams", Water Power and Dam Construction, 35(5), pp. 17-21 (1983).

2. Park, D. and Oh, J. "Permeation grouting for remediation of dam cores", Engineering Geology, 233, pp. 63-75 (2018).

3. Volkwein, A., Schellenberg, K., Labiouse, V., et al. "Rockfall characterization and structural protection a review", Nat. Hazard Earth Sys., 11, pp. 2617-2651 (2011).

4. Lambert, S. and Franck, B. "Design of rockfall protection embankments a review", Engineering Geology, 154, pp. 77-88 (2013).

5. Clough, R.W. and Woodward, J.J. "Analysis of embankment stresses and deformations", In Proc, ASCE, pp. 529-549(1967).

6. Chen, S., Gu, C., Lin, C., et al. "Multi-kernel optimized relevance vector machine for probabilistic prediction of concrete dam displacement", Engineering with Computers, 37(3), pp. 1943-1959 (2021).

7. Singh, D.N., Sivakugan, N., and Vanapalli, S.K. "Advances in instrumentation and monitoring in geotechnical engineering", Adva. in Civil Eng., 1, pp. 1-2 (2011).

8. Chen, X., Wu, Y., Yu, Y., et al. "A two-grid search scheme for large-scale 3-D finite element analyses of slope stability", Comp. and Geotechnics, 62, pp. 203215 (2014).

9. Rezaei, M. and Salehi, B. "The effect of changing the geometry and compaction degree on arching of earth dams", In Geo-Frontiers Congress, Amer. Soc. of Civil Eng., ASCE, pp. 3207-3216 (2011).

10. Wang, F., Dai, Z., Okeke, C.A.U., Mitani, Y., and Yang, H. "Experimental study to identify premonitory factors of landslide dam failures", Eng. Geology, 232, pp. 123-134 (2018).

11. Mahinroosta, R., Aliadeh, A., and Gatmiri, B. "Simulation of collapse settlement of first filling in a high rockfill dam", Eng. Geology, 187, pp. 32-44 (2015).

12. Little, T.E., Imrie, A.S., and Psutka, J.F. "Geologic and seismic setting pertinent to the dam safety review of Duncan dam", Can. Geot. J., 31, pp. 919-926 (1994).

13. Beiranvand, B. and Komasi, M. "Monitoring and numerical analysis of pore water pressure changes Eyvashan dam during the initial impounding period", J. App. Res. in Water and Wast, 6, pp. 1-7 (2019).

14. Seyed-Kolbadi, S.M., Hariri-Ardebili, M.A., Mirtaheri. M., and Pourkamali-Anaraki, F. "Instrumented health monitoring of an earth dam", Infrastructures, 5(3), p. 26 (2020).
15. Wang, S., Xu, Y., Gu, C., and Bao, T. "Monitoring models for base flow effect and daily variation of dam seepage elements considering time lag effect", Water Sci. Eng., 11, pp. 344-354 (2018).

16. Guo, X., Baroth, J., Dias, D., and Simon, A. "An analytical model for the monitoring of pore water pressure inside embankment dams", Engineering Structures, 160, pp. 356-365 (2018).

17. Javanmard, M., Amiri, F., and Safavi, S.M. "Instrumentation readings versus numerical analysis of Taham dam", Int. J. Eng., 32(1), pp. 28-35 (2019).

18. Rashidi, M., Heidar, M., and Azizyan, G. "Numerical analysis and monitoring of an embankment dam during construction and initial impounding (case study: Siah Sang dam)", Scientia Iranica, 25, pp. 505-516 (2018).

19. Hwang, R.N. "Back analyses in forensic geotechnical engineering", Geot. Eng., 4, pp. 1-8 (2016).

20. Gikas, V. and Sakellariou, M. "Settlement analysis of the Mornos earth dam (Greece) Evidence from numerical modeling and geodetic monitoring", Eng. Str., 30, pp. 3074-3081 (2008).

21. Zhou, W., Hua, J., Chang, X., and Zhou, C. "Settlement analysis of the Shuibuya concrete-face rockfill dam", Comp. and Geot., 38, pp. 269-280 (2011).

22. Delgado, J., Garrido, J., Lenti, L., Lopez-Casado, C., Martino, S., and Sierra, F.J. "Unconventional pseudo static stability analysis of the Diezma landslide (Granada, Spain) based on a high-resolution engineering-geological model", Eng. Geo., 184, pp. 8195 (2015).

23. Zhao, C., Lavasan, A.A., Barciaga, T., Zarev, V., Datcheva, M., and Schanz, T. "Model validation and calibration via back analysis for mechanized tunnel simulations-The Western Scheldt tunnel case", Comp. Geot., 69, pp. 601-614 (2015).

24. Zhao, K., Bonini, M., Debernardi, D., Janutolo, M., Barla, G., and Chen, G. "Computational modeling of the mechanized excavation of deep tunnels in weak rock", Com. Geot., 66, pp. 158-171 (2015).

25. Kutzner, C., Earth and Rockfill Dams Principles for Design and Construction, Routledge (2018).

26. Su, H., Zhiping, W., Shuai, Z., and Tian, Z. "Method for choosing the optimal resource in back-analysis for multiple material parameters of a dam and its foundation", J. Compute. Civ. Eng., ASCE, 30(4), 04015060 (2016).

27. Rashidi, M. and Haeri, S.M. "Evaluation of behaviors of earth and rockfill dams during construction and initial impounding using instrumentation, data and numerical modeling", Journal of Rock Mechanics and Geotechnical Engineering, 9, pp. 709-725 (2017).

28. Wen, L., Chai, J., Xu, Z., Qin, Y., and Li, Y. "Monitoring and numerical analysis of behaviour of 
Miaojiaba concrete-face rockfill dam built on river gravel foundation in China", Comput. Geotech, 85, pp. 230-248 (2017).

29. Pramthawee, P., Jongpradist, P., and Sukkarak, R. "Integration of creep into a modified hardening soil model for time-dependent analysis of a high rockfill dam", Comput. Geotech., 91, pp. 104-116 (2017).

30. Liu, C., Gu, C., and Chen, B. "Zoned elasticity modulus inversion analysis method of a high arch dam based on unconstrained lagrange support vector regression (support vector regression arch dam)", Eng. Comput., 33, pp. 443-456 (2017).

31. Cheng, L., Tong, F., Li, Y., Yang, J., and Zheng, D. "Comparative study of the dynamic back-analysis methods of concrete gravity dams based on multivariate machine learning models", Journal of Earthquake Engineering, 25(1), pp.1-22 (2021).

32. Lin, T., Li, X., Liu, L., Zhao, S., Chen, H., and Qi, A. "Deformation separation method for gravity dam body and foundation based on the observed displacements", Struct Control Health Monitor, 26(2), p. 2304 (2019).

33. Iran Water \& Power Resources Development Co "Laboratory tests report of rock mechanics for Rudbar dam and powerhouse and geomechanical parameters of dam and head race tunnel, Rudbar Lorestan dam and powerhouse plan", Second Phase Studies (2007).

34. Yu, Y., Zhang, B., and Yuan, H. "An intelligent displacement back-analysis method for earth rock fill dams", Com. Geot., 34, pp. 423-434 (2007).

35. Gioda, G. and Sakurai, S. "Back analysis procedures for the interpretation of field measurements in Geomechanics", Int. J. Num. Ana. Meth. Geom.", 11, pp. 555-583 (1987).

36. Cividini, A., Jurina, L., and Gioda, G. "Some aspects of characterization problems in Geomechanics", Int. J. of Rock Mech. Min. Scie. Geom. Abs., 18, pp. 487-503 (1981).

37. Jeon, Y.S. and Yang, H.S. "Development of a back analysis algorithm using FLAC", International
Journal of Rock Mechanics and Mining Sciences, SINOROCK2004 Symposium, 41, pp. 441-447 (2004).

38. Pan, Q., Xu, J., and Dias, D. "Three-dimensional stability of a slope subjected to seepage forces", Int. J. Geomech. 17(8), p. 4017035 (2017).

39. Waffaian, M., Executive Information on Earth Dams, First Edn., Isfahan: Ardakan Publications (2006).

\section{Biographies}

Vahed Ghiasi is an Assistant Professor of Geotechnical Engineering on Malayer University. His research interests are tunnel engineering, foundation engineering, soil mechanics, slope stability, and dam engineering. He has presented and published more than 100 papers in various international conferences and journals.

Farzad Heidari received his BSc degree in Civil Engineering from University of Jahad Khuzestan and his MSc degree in Civil Engineering from Malayer University. His research interests include numerical analysis, monitoring and instrumentation, computational mechanics and geomechanics, dam, and geotechnical and tunnel Engineering. He has presented and published several papers in various international conferences and journals.

Hossein Behzadinezhad graduated from Isfahan University of Technology in 2010 in the field of rock mechanics engineering (MSc). He has more than 10 years of executive experience in the fields of underground and open cuts, implementation of consolidation and maintenance system, and instrumentation and monitoring. He is currently working as the manager leading the stability control of the body of Rudbar Dam in Lorestan (Iran Water \& Power Resources Development Co). 